\title{
Yenidoğan Yoğun Bakım Ünitesinde Çalışan Hemşirelerin Yaşadığı Sorunlar: Nitel Bir Araştırma
}

\author{
The Problems of Nurses Working in the Newborn Intensive Care Unit: A Qualitative
}

Research

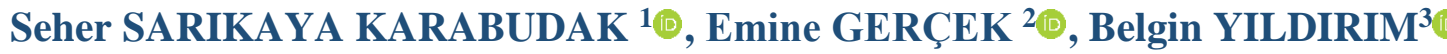 \\ ${ }^{1}$ Aydın Adnan Menderes Üniversitesi Hemşirelik Fakültesi Çocuk Sağlığı ve Hastalıkları Hemşireliği Anabilim Dalı, Aydın, \\ Türkiye \\ ${ }^{2}$ Aydın Adnan Menderes Üniversitesi Hemşirelik Fakültesi Doğum-Kadın Sağlığı ve Hastalıkları Hemşireliği Anabilim Dalı \\ Anabilim Dalı, Aydın, Türkiye \\ ${ }^{3}$ Aydın Adnan Menderes Üniversitesi Hemşirelik Fakültesi Halk Sağlığı Hemşireliği Anabilim Dalı Anabilim Dalı, Aydın, \\ Türkiye
}

ÖZ

\begin{abstract}
Amaç: Yenidoğan yoğun bakım ünitesinde (YYBÜ) çalışan hemşirelerin yaşadığı sorunları belirlemektir.
Yöntem: Çalışma niteliksel, fenomenolojik bir çalışmadır. Ocak-Ekim 2019 tarihleri arasında yapılmıștır. Çalıșmaya farklı hastanelerde çalışan 17 YYBÜ hemşiresi katılmıştır. Çalışmada araştırmacılar tarafından oluşturulan veri toplama formunda; sosyo-demografik verilerden oluşan birinci bölüm sekiz sorudan ve araştırma sorularının bulunduğu ikinci bölüm 12 açık uçlu sorudan oluşmaktadır. Veriler araştırmacılar tarafindan kodlanmış, tematik analiz yapılmıştır.

Bulgular: Çalışmaya katılan hemşirelerin yaş ortalaması 29.13 yıl ve YYBÜ'de çalışma süre ortalaması 5,73 yıldır. Hemşirelerin, 15'i üniversite mezunu, ikisi lise mezunu ve yedisi evlidir. Çalışma sonucunda dört tema belirlenmiştir: Sağlık sorunları, psikososyal sorunlar, mesleki sorunlar ve etik-manevi sorunlar

Sonuç: Hemşireler YYBÜ'de çalışmaktan dolayı varis gibi sağlık sorunları yaşamaktadır. Psikolojik, sosyal ve ekonomik olarak negatif etkilenmektedir. Mesleki hastalıklar açısından riskler taşımaktadırlar. Sağlık çalışanlarının sayı ve niteliğindeki yetersizlikler, cihaz ve malzeme sıkıntısı, hemşire başına düşen hasta sayısının standartları aşması ve buna bağlı bakım kalitesinde düşmeler gibi hasta bakımını etkileyen sorunlar yaşanmaktadır. Ekip arkadaşları, aileler ve amirlerle iletişim sorunları yaşadıkları saptanmıştır. Etik olarak; yararlılık, özerklik, adalet ve eşitlik ilkesinin ihlalinden duyulan rahatsızlıklar belirlenmiştir.
\end{abstract}

Anahtar Kelimeler: Yenidoğan yoğun bakım, Hemşire, Sorunlar.

\section{ABSTRACT}

Objective: It was planned to determine the problems experienced by nurses working in the neonatal intensive care unit (NICU). Methods: The study is a qualitative, phenomenological study and the study was conducted between January and October 2019.17 NICU nurses working in different hospitals participated. In the data collection form created by the researchers; the first part of social demographic data consists of eight questions and the second part of the study consists of 12 open ended questions. The data were coded by the researchers and thematic analysis was performed.

Results: The mean age of the nurses participating in the study was 29.13 . The average working time in the NICU is 5.73 years. Educational conditions; 15 of them are university graduates, 2 of them are high school graduates and 7 nurses are married. Four themes were identified as a result of the study: health problems, psychosocial problems, occupational problems and ethicalspiritual problems.

Conclusion: Nurses experience health problems such as varicose veins due to working in the NICU. Psychologically, socially and economically negatively affected. They carry risks in terms of occupational diseases. There are problems affecting the patient care, such as insufficiencies in the number and quality of healthcare workers, shortage of equipment and materials,

Sorumlu Yazar: Seher SARIKAYA KARABUDAK

Aydın Adnan Menderes Üniversitesi Hemşirelik Fakültesi Çocuk Sağlığı ve Hastalıkları Hemşireliği Anabilim Dalı,

Aydın, Türkiye

ssarikaya@adu.edu.tr

Geliş Tarihi: 26.11.2019 - Kabul Tarihi: 21.04.2020 
exceeding the number of patients per nurse and decreasing the quality of care. It was determined that they had communication problems with their teammates, families and superiors. Ethically; disturbances in violation of the principle of usefulness, autonomy, justice and equality.

Key words: Neonatal intensive care, Nurse, Problems.

\section{GíRiş}

Örgütlerde en değerli varlık olarak önemi anlaşılan insan faktörü, sadece fiziksel olarak çalışan olmaktan daha çok, duyguları, fikirleri, inançları, yetenekleri, bilgi ve becerileriyle örgüte katkı sağlayan temel unsurdur. İnsanın iş memnuniyeti bireyin iş hayatındaki başarısına, özel hayatındaki mutluluğuna hem de toplumsal huzura katkı sağlar. Çalışanların işlerine karşı hissettikleri kümülatif duygularla ilgili olan iş tatmini, hem akademik alanda hem de iş hayatında örgütler tarafindan önem verilen bir konudur. Yönetim uzmanları ve örgütsel psikologlar, insan performansını etkileyen faktörlere odaklanmıştır (1-3).

Hemşirelik mesleği, zor çalışma koşulları, uykusuzluk, yorgunluk, yeterince belirlenmemiş yetki ve sorumluluklar, acı çeken veya hayati tehlikesi bulunan hastaya hizmet verme gibi nedenlerle genel olarak zor ve stresli bir meslektir (4). İş ortamında yaşadığı gerginlikler, huzursuzluklar, yetersizlikler vb. pek çok sorun nedeniyle stres altına giren hemşireler hem bedensel hem ruhsal olarak rahatsızlanmakta, iş kaybı meydana gelmektedir. Sağlık sektörü, insan yaşamının söz konusu olduğu kritik bir çalışma sahasıdır. Yapılan en ufak bir hatanın bile sonucunun insan hayatı olması nedeniyle bu alanda çalışanların yaşadığı tatmin ve tatminsizlik sadece bireysel açıdan değil, toplumsal açıdan da kritik bir öneme sahiptir. Sağlık personelinin yaşadığı tatmin, hasta ve hasta yakınlarına pozitif etki etmektedir (1). Üçüncü binyılın temel hedeflerinden biri bebeklerde ve çocuklarda ölüm oranını azaltmaktır. Hizmet kalitesini artıran faktörler açıkça ölüm oranını azaltacaktır. Ayrıca birer işletme olan hastaneneler açısından bakıldığında, yaşanan sorunlar ciddi maliyet ve zaman kaybına neden olabilmektedir. İnsan kaynakları hizmet kalitesini etkileyebileceği için mevcut durumu ve sorunları belirlemek, stresleri azaltmak veya ortadan kaldırmak için planlama stratejileri, insan kaynaklarının verimliliğini ve dolayısıyla bakım hizmetlerinin kalitesini kesinlikle en üst düzeye çıkarabilir. Sorunları çözülen hemşirelerin iş doyumu artacak, dolayısıyla sağlık personelinin iş tatmini, hastalara ve kurumun kendisine direkt olarak etki edecektir $(1,2)$.

$\mathrm{Bu}$ nedenlerle bu çalışma; yenidoğan yoğun bakım ünitesinde (YYBÜ) çalş̧an hemşirelerin yaşadığı sorunları belirlemek amacıyla planlanmıştır.

\section{GEREÇ VE YÖNTEMLER}

Çalışma niteliksel, fenomenolojik bir çalışmadır. Ocak-Ekim 2019 tarihleri arasında yapılan çalışmaya farklı hastanelerde çalışan 17 YYBÜ hemşiresi katılmıştır. Benzeşik (homojen) ve ölçüt örnekleme yöntemi kullanılmıştır. Araştırmaya katılma ölçütü olarak en az 3 aydır YYBÜ çalışıyor olma durumu belirlenmiştir.

Çalışmada araştırmacılar tarafından oluşturulan veri toplama formunda sosyodemografik verilerden oluşan birinci bölüm sekiz sorudan ve araştırma sorularının bulunduğu ikinci bölüm 12 açı uçlu sorudan (sağlık, çevre, iletişim sorunları, ekonomik, sosyal, spritüel, etik sorunlar gibi) oluşmaktadır. Araştırma veri formu e- mail aracıllğıyla hemşirelere gönderilmiş, çalışmaya katılmaya gönüllü olan hemşireler gönderilen veri 
formundaki soruları yanıtlandıktan sonra araştırmacılara geri göndermişlerdir. Yaklaşık bir ay sonra dönüş yapmayan hemşirelere bir kere daha mail gönderilmiş, iki mail sonrasında geri dönüş yapmayan bir hemşire olmuştur. Gönderilen Microsoft Word belgeleri araştırmacılar tarafından kodlanmış, kodlar araştırmacılar tarafından sınıflandırılmış, uygun temalar ve alt temaları oluşturmaya yönelik tematik analiz yapılmıştır. Araştırmanın geçerliğini arttırmak için aynı işlem üç uzman araştırmacı tarafından yapılmış ve ortak belirlenen temalara göre araştırmacılar tarafından yeniden düzenlenmiştir. Ardından tüm veriler temalara göre yorumlanarak rapor haline getirilmiştir.

\section{BULGULAR}

Çalışmaya katılan hemşirelerin yaş ortalamaları 29.13 (Min=24, Max=42), yenidoğan yoğun bakım ünitesindeki çalışma süreleri ortalama 5.73 (Min=1, Max=15) yılken toplam hemşirelik süreleri 10 (Min=4, Max: 23) yıldır. Hemşirelerin 15'i üniversite mezunu, 2'si lise mezunudur ve yedi hemşire evlidir. İki üniversiteden 14 hemşire ve iki devlet hastanesinden üç hemşire olmak üzere toplam 17 hemşire çalışmaya katılmıştır. YYBÜ’ler düzey 2-3 yoğun bakımlardır.

Çalışmada dört tema ve bunların altında gruplanmış alt temalar bulunmaktadır (Tablo1).

Tablo 1. Yenidoğan Yoğun Bakım Ünitesinde Çalışan Hemşirelerin Yaşadığı Sorunlara Ait Temalar

\begin{tabular}{llll}
\hline 1. Sağlık Sorunları & $\begin{array}{l}\text { 2. Psikososyal } \\
\text { Sorunlar }\end{array}$ & $\begin{array}{l}\text { 3. Mesleki } \\
\text { Sorunlar }\end{array}$ & $\begin{array}{l}\text { 4. Etik-Manevi } \\
\text { Sorunlar }\end{array}$ \\
\hline & Psikolojik & Riskler & Etik \\
& Hasta bakımı & \\
& Sosyal & $\begin{array}{l}\text { Teorik bilgi eksikliği } \\
\text { Çevre/ortam }\end{array}$ & Maneviyat \\
& İletişim & \\
\hline
\end{tabular}

\section{Tema 1: Sağlık Sorunları}

Hemşirelerin en çok ifade ettiği sağlık sorunları varistir. Sirkadyen ritmde bozulmalara bağlı uyku sorunları ve omurga sağlığındaki bozulmalara bağlı boyun, sırt, bel ağrıları ve fitıklar diğer en çok belirtilen sorunlar olmuştur. Yorgunluk- halsizlik, baş ağrısı, ayak-bacak ağrıları ve ödemi, vücut direncinin düşmesi, kifoz, mide problemleri, göz kuruluğu, özellikle ellerde sık el yıkamaya ve kalitesiz sabunlara bağlı cilt bütünlügünde bozulma, düzensiz beslenmeye bağlı kilo problemleri diğerleridir. İşitme problemleri, kanser ve kalp damar hastalıkları açısından da risk altında olduklarını düşünmektedirler.

\section{Tema 2:Psikososyal Sorunlar}

Psikolojik olarak en çok dile getirilen sorun stres-gerginlik olmuştur. Hemşirelerin tümü bu sorunu yaşadığını ifade etmiştir. Daha sonra tükenmişlik ve tahammülde azalma, anksiyete, depresif bulgular, sese aşırı duyarlılık ve tahammül edememe, umutsuzluk, mesleki doyumda azalma, aileye zaman ayıramama nedeniyle ailedeki rollerinde yetersizlik hissi, kayıp- yas ve değersizlik gibi duyguların yaşandığı ifade edilmiştir.

Sosyal olarak hemşireler ciddi sorunlar yaşadıklarını ifade etmişlerdir. Hemşireler bu sorunu şöyle dile getirmiştir: 
"YYBÜ de kapalı bir ortamda çalıştığımız için gerek hastane içi gerek hastane dışı sosyal ortamımız çok fazla olmuyor... Yoğun çalışma saatlerinden ötürü sosyal aktivitelere katılacak zamanımız olmuyor"(H-16).

"Yaşanan sosyal sorunlar; tüm enerjimizi iş yerinde harcadığımı için kendimize de ailemize de yeterli zaman ayıramamak, sosyal hayatı yaşayamamak”(H-1).

Ekonomik açıdan ise hemşireler genel emeklerinin karşılığ düşünmektedirler. Döner sermayeden alınan paylarda hekimlere yönelik yan tutmanın olduğu ve hemşirelik uygulamalarından hak ettikleri ücreti alamadıklarını belirtmişlerdir.

\section{Tema 3: Mesleki Sorunlar}

Riskler alt teması açısından en çok ifade edilen mesleki risk, enfeksiyon kapma olasılığı olmuştur. Erken yıpranma, hukuksal yönden risk altında olma, çok küçük doz ilaçların uygulanması ve bağımlı hasta grubu olması gibi nedenlerle malpraktis riskinin diğer çalışma alanlarına göre daha yüksek olması, en küçük bir dalgınlığın hastanın hayatına mal olabilmesi, ilaç, kimyasallar ve radyasyon gibi teratojenler ile şiddete maruz kalma gibi mesleksel riskler ifade edilmiştir.

Hasta bakımına yönelik olarak ifade edilen en büyük sorun sağlık çalışanlarının sayı ve niteliğindeki yetersizliklerdir. Cihaz ve malzeme sıkıntısı, hemşire başına düşen hasta sayısının standartları aşması ve buna bağlı bakım kalitesinde düşmeler, yoğun bakım standartlarına uygun olmayan hastaların yoğun bakıma yatırılması, ayrı bir emzirme hemşiresinin olmaması, hemşire görev yetki ve sorumlulukları dışında işler yapmak zorunda bırakılmak diğer ifade edilen bakıma yönelik sıkıntılardır. Hemşireler özellikle preterm bebeklerde damar yolu açma gibi işlemler için çok zorlandıklarını ifade etmişlerdir.

Ayrıca birlikte çalıştıkları ekip arkadaşları hekimlerle hasta bakımına yönelik bazı zorluklar yaşadıklarını dile getirmişlerdir. Hekimler tarafından bağımsız hemşirelik fonksiyonlarına müdahale edilmesi, hekimlerin aynı hasta için çok farklı istemler vermesi, verilen istemlerin net olmaması ve hekimlerin bebekle ilgili hemşire gözlemlerini dikkate almaması gibi sorunların hasta bakımını negatif etkilediği belirtilmiştir.

Teorik bilgi açısından ise; en çok ilaç uygulamaları ile ilgili bilgi eksikleri (ilaç etkileşimleri, muadilleri, doz hesaplamaları, ilaç etki ve yan etkileri gibi) dile getirilmiştir. Lisans eğitiminde hiç yenidoğan görmeden mezun olunması, yeni bilgi ve değişiklikleri takip edememe, nadir karşılaşılan hastalık ve bozukluklularla karşılaşma gibi durumlarda teorik bilgi ihtiyacı hissettiklerini açıklamışlardır. Bu tür teorik bilgi eksikliklerinin hasta bakım kalitesini düşürdüğünü, ekip üyelerinin ve ailenin hemşireye olan güvenini etkilediğini belirtmişlerdir.

Çevre/ortam nedeniyle yaşanan sorunlar: Hemşireler monitör, kuvöz vb. cihaz alarmlarının oluşturduğu gürültü ve aydınlatmalar nedeniyle yüksek 1şık bulunan bir ortamda günün yarısından fazlasını geçirmek zorunda kaldıklarını belirtmişlerdir. Ayrıca ortamın yoğun bakım standartlarına uygun olmadığı, ergonomik olmayan ve beden mekaniğini desteklemeyen bir yapısı olduğu ifade edilmiştir. Bir hemşire "16 saat boyunca nöbet tuttuğumuz bir klinikte hemşire konforu hiç düşünülmemiş...” (H-11) şeklinde ifadeler yazmıştır. Kolaylıkla açılabilen kapılar nedeniyle güvenliğin yeterli sağlanamayışı, hemşire istasyonundan tüm hastalara aynı anda hakim olamama nedeniyle hastayı görebilmek için sürekli ayağa kalkmak zorunda olma, ortamın serin olmasına bağlı üşüme, sürekli kameraya çekilme nedeniyle rahat olamama diğer ifade edilen çevresel sorunlardır. 
İletişim: Stres faktörü fazla bir ortamda çalışmak nedeniyle ekip arkadaşları, özellikle hekimler ile çatışma yaşama en sık tekrarlanan sorun olmuştur. Yapılan işin ekip işi olmasına rağmen bireysel çalışanların olması, insanların birbirini dinlememesi, profesyonel olmayan dil kullanımı ekip üyeleri ile olan iletişim sorunları olarak karşımıza çıkmıştır.

Ailelerle ise şöyle sorunlar yaşandığı yazılmıştır:

"Ailelerin yoğun stres ve lohusalık gibi nedenlerle iletişime kapalı olması, iletişim kurmada zorluk yaşama”(H-11).

"Farkl kültürlerden anne - babayla iletişim zorluğu”(H-12).

Ayrıca bazen hemşirelerin de yorgunluk tükenmişlik gibi nedenlerle aileyle iletişime kendisini kapattığını belirtmişlerdir.

İletişim sorunları konusunda üzerinde durulan bir diğer sorun amirler ya da kıdemli çalışanlar ile yaşandığı görülmüştür. Kıdemli çalışanların kendisini üstün görmesi, amirlerin anlatılan sorunları anlamaması-önemsememesi ve mobbing uygulanması ifade edilen sorunlardir.

\section{Tema 4: Etik ve Manevi Sorunlar}

Etik olarak; hemşireler meslektaşları ya da sağlık çalışanları ile ilgili etik sorunları en sıklıkla dile getirmişlerdir.

"Sağllk çalışanlarının bir kısmının, sosyal ve ekonomik düzeyi yüksek hastalara diğerlerinden çok daha ayrıcalıkl davranmalarl etik bir sorun”(H-12).

Hekimlerin hemşire uyarılarını dikkate almaması, gereksiz müdahale ve tetkik istemleri nedenleriyle bebeklerin iyileşme sürecinin etkilenmesi veya kalıcı sorunların gelişmesi, hekimlerin doğru olmayan uygulamalarına karşı hemşirelerin ya da meslektaşlarının bir şey yapamaması, hemşirelerin sözel istemi yapmak zorunda kalması ancak hekimlerin verdikleri sözel istemlerin arkasında durmaması gibi etik sorunlar belirtilmiştir. Üniteye yoğun bakım standartına uymayan hasta yatırılması ya da zamanında taburcu edilememesi nedenleriyle asıl ihtiyacı olan hastaların yoğun bakımdan mahrum kalması etik sorun olarak sunulmuştur.

Maneviyat /spritualite açısından ise bebeklerin kaybına dayanmakta güçlük çekme ve yas yaşama, bebeklerin acıları hak etmediklerine inanma, yoğun bakım sonrası kalıcı sekellerin oluşmasına çok üzülme gibi olumsuz yaşantıların yanında olumlu bir takım sprituel inaçlar hemşirleri rahatlatmaktadır: "meleklere hizmet verdiğimi düşünüyorum, bu beni mutlu hissettiriyor" (H-16).

Aileye yardım etmekle ve isteklerini yerine getirmeye çalışmakla, aile ve bebek arasında bağı kurmaya çalışmak ile mutlu olduklarını anlatmaya çalışmışlardır. Kendi dinsel inanışlarına yönelik uygulamalarda zorluk yaşadıklarını belirtmişlerdir: "ramazanda oruç tutamıyoruz " $(H$ 17).

\section{TARTIŞMA}

\section{Săglık Sorunlart}

Hemşirelik bazı sağlık risklerini beraberinde taşıyan mesleklerden biridir. Fazla ayakta kalmak nedeniyle oluşan hastalılardan biri olan varis YYBÜ hemşireleri tarafından en fazla dile getirilen hastalık olarak göze çarpmaktadır. Vardiyalı çalışma nedeniyle oluşması doğal olan uyku problemleri sirkadyen ritmin sürekli değişmesi nedeniyle ortaya çıkmaktadır. Yine beden mekaniğine dikkat etmemeye bağlı geliştiği düşünülen boyun, sırt, bel ağrıları ve fitıklar, kifoz 
belirtilen sağlık sorunları olmuştur. Yoğun çalışma temposunun hem fiziksel hem psikolojik olarak etki ederek; yorgunluk- halsizlik, baş ağrısı, ayak-bacak ağrıları ve ödemi, vücut direncinin düşmesi, mide problemleri gibi sorunlara yol açmış olabileceği düşünülmektedir. Fazla aydınlatma ve 1şıklar nedeniyle göz kuruluğu, yüksek ses ve gürültüye bağlı işitme problemleri, özellikle ellerde sık el yıkamaya ve kalitesiz sabunlara bağlı cilt bütünlüğünde bozulma, düzensiz beslenmeye bağlı kilo problemleri ifade edilen diğer sağlık problemleridir. Hemşireler çevresel riskler ve stres nedeniyle kanser ve kalp damar hastalıkları açısından da risk altında olduklarını düşünmektedirler.

\section{Psikososyal Sorunlar}

Çalışmamızda hemşirelerin tümü psikolojik olarak en çok stres-gerginlik yaşadığını belirtmiştir. Daha sonra tükenmişlik ve tahammülde azalma, anksiyete, depresif bulgular, sese aşırı duyarlılık ve tahammül edememe, umutsuzluk, mesleki doyumda azalma, aileye zaman ayıramama nedeniyle ailedeki rollerinde yetersizlik hissi, kayı- yas ve değersizlik gibi duyguların yaşandığı ifade edilmiştir.

Hindistan'da yapılan bir nicel çalışmada da hemşirelerin algılanan ortalama stres seviyesi ortalamanın üzerinde çıkmış, yüksek tükenmişlik \%23.3 ve yüksek ikincil travmatik stres \%23.3 olarak bildirilmiştir (5). Bir başka çalışmada YYBÜ hemşirelerinin orta derecede tükenmişlik yaşadıkları ve bu durumun hemşirelerin yaşam kalitesini etkilediği belirlenmiştir (6). Genel olarak sağlık çalışanlarının psikolojik bozukluklar açısından genel insan popülasyonundan daha riskli durumda olduğu belirlenmiştir (7). Ancak YYBÜ çalışanların depresyon ve kaygı gibi sorunlar açısından servis çalışanlarından da daha fazla risk taşıdıkları gösterilmiştir (4). Buradan hareketle özellikle YYBÜ çalışanlarının stresle başa çıkma yolları konusunda bilgi ve becerileri geliştirilerek yaşam kalitesi ve psikolojik sağlamlık düzeylerinin arttırılabileceği düşülmektedir.

Sosyal yaşam açısından hemşireler ağır çalışma koşulları nedeniyle aile ve sosyal hayatlarına zaman ayıramadıklarını, zamanları kalsa da enerjilerinin kalmadığını anlatmışlardır. Literatürde YYBÜ hemşirelerinin sosyal yaşamlarıyla ilgili sorunları inceleyen çalışmaya rastlanmadığı için bu çalışma sonucu farklı bir bakış açısı ortaya koyan önemli bir sonuçtur.

Ekonomik açıdan ise genel olarak hem hemşire olarak, hem de çalışılan kliniğe bağlı yoğunluk ve risklere rağmen hak ettikleri, emeklerinin karşılığı olan ücreti alamadıklarını düşünmektedirler. Döner sermayeden alınan paylarda da adaletsizlik olduğu, hekimlere yönelik yan tutmanın olduğu ifade edilmiştir. Küçük ve Yağmur'un nicel çalışmasında YYBÜ çalışan hemşirelerinin ücret yetersizliğini önemli bir stresör olarak belirttiği görülmektedir (8). Hindistan'da farklı olarak YYBÜ'de çalışan hemşirelerin maaşlarından memnun oldukları bildirilmektedir (5).

Literatürde sağlık çalışanlarının genel olarak psikososyal riskleri; ilaç, alkol, madde bağımlılığı, stres, şiddet gibi riskler olarak belirtilmektedir. Ancak çalışmamızda YYBÜ'de çalışmak nedeniyle hemşireler çok daha ayrıntılı ve farklı bir psikososyal sorunlar listesi ortaya koymuşlardır $(9,10)$.

\section{Mesleki Sorunlar}

Riskler alt teması altında hemşireler; enfeksiyon ve teratojenlere maruziyet nedeniyle sağlık risklerinin olduğunu belirtmişlerdir. Ayrıca bakılan hasta popülasyonunun özelliği 
nedeniyle çok daha yüksek malpraktis ve hukuksal sorun yaşama riski altında olduklarını düşünmektedirler.

Hasta bakımına yönelik yaşanan en büyük sorunun ise; sağlık çalışanlarının sayı ve niteliğindeki yetersizlik olduğu yanı sıra cihaz, malzeme ve fiziki şartlardaki yetersizliklerin de hasta bakımını negatif etkilediği belirtilmiştir. YYBÜ'de yatan hasta popülasyonunun bebekler olmasının yapılan işlemleri zorlaştırdığı ve yapılma sürelerini uzattığı ifade edilmiştir. Hemşire görev yetki ve sorumlulukları dışında işler yapmak zorunda bırakıldıklarını ifade edenler olmuştur. Hem bakılan hasta popülasyonun özel bir grup olması hem de bakım için harcanması gereken zamanın hemşirelik dışı işlere harcanması hemşirelerin etkili zaman yönetimini negatif etkilemektedir. Ayrıca hekimler tarafından bağımsız hemşirelik fonksiyonlarına müdahale edilmesi, hekimlerin aynı hasta için çok farklı istemler vermesi, verilen istemlerin net olmaması ve hekimlerin bebekle ilgili hemşire gözlemlerini dikkate almaması gibi sorunların hasta bakımını negatif etkilediği belirtilmiştir.

Küçük ve Yağmur çalışmalarında YYBÜ hemşireleri baktıkları hasta sayısının fazla olduğunu ve bakılan ortalama hasta sayısının artmasının hemşirelerin iş stresini de arttırdığını bildirmişlerdir (8). Bizim çalışmamıza benzer bir bulgu Çınar'ın (2007) çalışmasında ortaya konmuştur: Genel olarak yoğun bakım hemşireleri ile yapılmış nicel çalışmada, hemşirelerin önemli bir kısmı, hemşire ve yardımcı personel yetersizliğinin, malzeme eksikliği ve kalitesinin kötü oluşunun, fiziksel mekan, ortam şartları ve donanımın uygun olmayışının, iş yükü ve çalışma saatlerinin fazla oluşunun, bakımda standartlarının olmayışı ile görev, yetki, sorumluluklarının net olmayışının, hastalara verilen hemşirelik bakımını olumsuz yönde etkilediğini düşündükleri saptamıştır (11). Amin ve arkadaşlarının (2015) yaptığı çalışmada YYBÜ'de çalışan hemşirelerin ortalama 8 saat çalıştıkları ve yaklaşık \%44 ünün dörtten fazla hasta/vardiya baktığ bildirilmektedir (5).

Teorik bilgi eksikliği ile ilgili sorunlar mevcuttur ve hemşireler bu tür teorik bilgi eksikliklerinin hasta bakım kalitesini düşürdügünü, ekip üyelerinin ve ailenin hemşireye olan güvenini etkilediğini belirtmişlerdir. Farklı bir çalışmada bireyselleştirilmiş gelişimsel bakım, aile merkezli bakım gibi bakım felsefelerinin Türkiye 'deki YYBÜ hemşireleri tarafından yeterli düzeyde bilinmediği ve uygulanmadığı bildirilmiştir (12). Bu durumda sağlık personellerine yönelik düzenlenen hizmet içi eğitimlerin bu ihtiyaçları karşılamaya yönelik planlanması önemlidir. Ayrıca çoğunluğu üniversite mezunu olan hemşirelerin teorik bilgi ihtiyacını dile getirmesi, hemşirelik eğitim kurumlarının eğitim kalitesini, uzaktan eğitim ya da lisans tamamlama gibi uygulamaları gözden geçirmesini gerektirir.

Çevre/ortam ile ilgili sorunlar; gürültü, aydınlatma ve 1sı sorunları, ortamın yoğun bakım standartlarına uygun olmayışı, ergonomik olmayan ve beden mekaniğini desteklemeyen çevredir. Ayrıca güvenlik açısından risklerin olduğu, hastaların sürekli gözlenebilmesinin sağlanamadığı, ortamında bulunan kameralar nedeniyle sürekli kameraya çekilmenin kişilerde gerginlik yarattığı ifade edilen diğer çevresel sorunlardır.

Aydınlatma, havalandırma ve gürültü gibi fiziksel faktörlerin yoğun bakım çalışanlarının stres kaynaklarından olduğu bildirilmektedir $(13,14)$. Çalışmalarda farklı oranlarda da olsa hemşirelerin uygun olmayan fiziksel koşullardan şikayet ettikleri görülmüştür $(9,15)$. Anayasa'da "herkesin sağlıklı ve güvenli bir çevrede yaşama hakkına sahip olduğu" hükmü yer almaktadır (Madde 56) (Türkiye Cumhuriyeti Anayasası). Bu nedenle kurumların 
iş güvenliği çerçevesinde sağlıklı ve güvenli bir çevre oluşturma yükümlülüklerini yerine getirmesi önemlidir (16).

Iletişim ile ilgili sorunlar açısından çalışmamızda hemşireler ekip arkadaşları, amirleri ve aileler ile farklı boyutlarda iletişim sorunlarından bahsetmişlerdir. Küçük ve arkadaşlarının çalışmasında da meslektaş ve hekimler ile iletişim problemi yaşamanın stres düzeylerini arttırdığı belirtilmiştir. Ayrıca yapılan işin değersiz/önemsiz görülmesi de stres düzeyini etkileyen bir sorun olarak saptanmıştır (8). Özellikle iş arkadaşları ve amirlerle yaşanan sorunlar, hemşirelerin iş doyumuna çok önemli etkiler yaptığ 1 için çözüm stratejileri geliştirilmesi çok önemlidir (2). İran'da yapılan çalışmada, YYBÜ'de çalışan hemşireler için çevresel ve insan faktörlerinin en önemli stresörler olduğu bildirilmektedir (3). Ülkemizdeki bulgulardan farklı olarak Hindistandaki YYBÜ hemşireleri iş ortamındaki ilişkileri genel olarak “iyi” ile "mükemmel” tanımlamışlardır (5). Kültürün ve çalışma şartlarının farklı olması farklı sonuçlar ortaya çıkmasına yol açabilir. Bu farklılıklar incelenerek iyileştirme çalışmalarına bir çatı oluşturulabilir.

Literatürde genel olarak sağlık çalışanlarının karşılaştıkları risklerin: 1) Biyolojik riskler (Hepatit-B, tüberküloz, HIV/AIDS ve diğer bulaşıcı hastalıklar gibi), 2) Fiziksel riskler (aydınlanma, gürültü, radyasyon gibi), 3)Kimyasal riskler (anestezik gazlar, sitotoksik ilaçlar, sterilizasyon malzemeleri gibi), 4) Ergonomik riskler (uygun olmayan çalışma ortamı gibi tasarımdan kaynaklanan) olduğu ve bu risklerden dolayı sağlık çalışanlarının hastalandığı, yaralandığı, sakat kaldığı ya da ölebildiği belirtilmektedir $(9,10)$. Çalışmamızdaki YYBÜ hemşireleri benzer mesleki riskleri ayrıntılı olarak tanımlamışlardır.

\section{Etik ve Manevi Sorunlar}

Hemşireler yaşadıkları etik sorunları açıklarken etik ilkeler temel alındığında, zarar vermeme-yararlılık ilkesinin, özerklik-bireye saygı ilkesinin, adalet ve eşitlik ilkesinin (17) ihlalinden duydukları rahatsızlıkları dile getirmeye çalışmışlardır.

Hekimlerin hemşire uyarılarını dikkate almaması, gereksiz müdahale ve tetkik istemleri nedenleriyle bebeklerin iyileşme sürecinin etkilenmesi veya kalıcı sorunların gelişmesi, hekimlerin doğru olmayan uygulamalarına karşı hemşirelerin ya da meslektaşlarının bir şey yapamaması, hemşirelerin sözel istemleri yapmak zorunda kalması ancak hekimlerin verdikleri sözel istemlerin arkasında durmaması gibi etik sorunlar zarar vermeme- yararlılık ilkesinin ihlalinden duyulan rahatsızlığı ortaya koyan açıklamalardır. Bir hemşire tarafından dile getirilen "Sağlık çalışanlarının bir kısmının, sosyal ve ekonomik düzeyi yüksek hastalara diğerlerinden çok daha ayrıcalıklı davranmaları etik bir sorun"(H-12) açıklaması adalet ve eşitlik ilkesinin ihlalinden duyulan rahatsızlığı ifade ediştir. Üniteye yoğun bakım standartına uymayan hasta yatırılması ya da zamanında taburcu edilememesi nedenleriyle asıl ihtiyacı olan hastaların yoğun bakımdan mahrum kalması da sağlı hizmetlerinin adil dağıtılmasını engelleyen bir sorun olarak düşünülebilir. Esen in çalışmasında YYBÜ de çalışan ebe ve hemşirelerin yaşadıkları etik ikilemler nicel tanımlayıcı bir çalışma ile incelenmiş; mesleki profesyonellik artışı ile etik ikilemler karşısında karara dahil olma isteğinin arttığı, ebe ve hemşireler tarafından nafile tedavi kavramının benimsenmiş olmasına rağmen yenidoğana dair yaşamsal bir karar verilirken "yenidoğanın yaşam hakkı"nı savunan bir tutum içerisinde oldukları saptanmıştır (18). Her iki çalışmada muhtemelen yöntemsel farklılıklar nedeniyle farklı konular üzerinden tartışılsa da YYBÜ'de çalışan hemşirelerin pek çok etik ihlali fark 
ettikleri, etik ilkeleri korumaya çalıştığı ancak desteklenmeye ihtiyaçlarının oldukları söylenebilir.

Maneviyat alt teması ile ilgili ifade edilen genel olarak; yaşanan kayıp sürecinde acı çekme, üzüntü gibi duygular ve bunlarla baş etmek için kullanılan spritüel inançlardır. Ayrıca hemşireler kendi dinsel inançlarının bazılarını (oruç tutma gibi) yerine getirme konusunda çalışma şartlarının zorlayıcı etkisinden bahsetmişlerdir.

\section{SONUÇ VE ÖNERIILER}

Hemşireler YYBÜ'de çalışmaktan dolayı varis gibi sağlık sorunları yaşadıklarını, psikolojik, sosyal ve ekonomik olarak negatif etkilendiklerini belirtmişlerdir. Mesleki hastalıklar açısından riskler taşımaktadırlar. Sağlık çalışanlarının sayı ve niteliğindeki yetersizlikler, cihaz ve malzeme sıkıntısı, hemşire başına düşen hasta sayısının standartları aşması ve buna bağlı bakım kalitesinde düşmeler gibi hasta bakımını etkileyen sorunlar yaşanmaktadır. Gürültü, yoğun 1şık gibi çevresel uyaranları ve standarlara uygun olmayan ortam faktörlerini çevresel sorunlar olarak tanımlamışlardır. Ekip arkadaşları, aileler ve amirlerle iletişim sorunları yaşadıkları saptanmıştır. Etik olarak; yararlılık, özerklik, adalet ve eşitlik ilkesinin ihlalinden duyulan rahatsızlıklar belirlenmiştir. Manevi olarak yas ve kayıp duygularıyla başetmek için bazı inançları kullanmakta, dinsel yaşantılarıyla ilgili zorluk yaşayabilmektedirler.

YYBÜ çalışan hemşireler pek çok sağlık sorunu yaşamakta, psikososyal açıdan etkilenmekte, mesleki, etik ve manevi açılardan sorunlarla karşılamakta ve baş etmek zorunda kalmaktadırlar. İnsan kaynaklarının verimliliğini ve dolayısıyla bakım hizmetlerinin kalitesini en üst düzeye çıkarabilmek için hemşirelerin yaşadığı sorunları gidermeye, stresörleri azaltmaya veya ortadan kaldırmaya yönelik planlama stratejileri belirlenmelidir.

\section{KAYNAKLAR}

1. Adıgüzel, O., Keklik B. (2011). Sağlık kurumlarındaki iş görenlerin iş tatmini ve bir uygulama. Dumlupınar Üniversitesi Sosyal Bilimler Dergisi, 29, 305-18.

2. Aytekin, A. (2014). Yenidoğan Yoğun Bakım Kliniği'nde çalışan hemşirelerde iş doyumu ve etkileyen faktörler. İzmir Dr. Behçet Uz Çocuk Hast. Dergisi, 4(1), 51-58. doi:10.5222/buchd.2014.051.

3. Valizadeh, L., Farnam, F., Zamanzadeh, V., Bafandehzendeh, M. (2012). Sources of stress for nurses in neonatal intensive care units of east azerbaijan province, Iran. $J$ Caring Sci. 1(4), 245-254. doi: 10.5681/jcs.2012.034.

4. Yalaz, M., Solak, U., Arslan, M., Şen, A., Köroğlu, Ö., Akısu, M. ve ark. (2009). Yenidoğan yoğun bakım hemşirelerinde stres faktörleri ve stresle başetmenin değerlendirilmesi: Karşılaştırmalı bir çalışma. Ege Pediatri Bülteni, 16(3), 143-8.

5. Amin A. A., Vankar J. R., Nimbalkar1 S. M., Phatak A. G. (2015). Perceived Stress and Professional Quality of Life in Neonatal Intensive Care Unit Nurses in Gujarat, India. Indian J Pediatr, 82(11):1001-1005. doi: 10.1007/s12098-015-1794-3

6. Aytekin A., Kuğuoğlu S., Yılmaz F. (2013) Burnout levels in neonatal intensive care nurses and its effects on their quality of life. Australıan Journal Of Advanced Nursing, 31(2), 39-47.

7. Wall, T., Bolden, R., Borrill, C. et al. (1997) Minor psychiatric disorder in NHS trust staff: occupational and gender differences. Br J of Psych,171, 519-523. 
8. Küçük, S., Yağmur, B. (2018). Yenidoğan yoğun bakım ünitesi hemşirelerinin iş stresini etkileyen faktörler ve algılanan iş stresi düzeyleri. Akademik Sosyal Araşstırmalar Dergisi, 6(72),142-152.

9. Çelikalp Ü.(2015). Tekirdağ ilinde görev yapan hamile ebe ve hemşirelerin mesleki risk etmenleri ile bu etmenlerin gebelik süreci ve yenidoğan bebeklerine etkilerinin değerlendirilmesi. Trakya Üniversitesi Sağlık Bilimleri Enstitüsü Halk Sağlı̆̆ Anabilim Dalı İş Sağlığı Doktora Programı, (Yayınlanmamış Doktora Tezi), Edirne.

10. Beşer A. (2012). Sağlık çalışanlarının sağlık riskleri ve yönetimi. Sağlık çalışanlarının riskleri. DEUHFED,5(1):39-44.

https://acikerisim.deu.edu.tr/xmlui/bitstream/handle/20.500.12397/4607/beser_3944.pdf? sequence $=1 \&$ isAllowed=y. (Erişim Tarihi: Ocak 2020)

11. Çınar, E. (2007). Trakya Üniversitesi Hastanesi ve Edirne Devlet Hastanesi yoğun bakım birimlerinde çalışan hemşirelerin, hemşirelik bakımı hizmetlerinin değerlendirilmesi. Trakya Üniversitesi Sağlık Bilimleri Enstitüsü (Yayınlanmamış Yüksek Lisans Tezi), Edirne.

12. Çağlar, S., Dur, Ş., Sönmez Düzkaya, D., Koç Özkan, T., Torun, N., Çiğdem, Z., ve ark. (2019). Türkiye'deki yenidoğan hemşirelerinin profilleri ve bireyselleştirilmiş gelişimsel bakıma yönelik uygulamaları. Jaren, 5(2),132-140. doi:10.5222/jaren.2019.42104.

13. Mokhtar, K., El Shikieri, A., Taha, E. M. Rayan, A. (2016). The relationship between occu-pational stressors and performance amongst nurses working in pediatric and intensive care units. American Journal of Nursing Research, 4 (2), 34-40.

14. Morrison, W. E., Haas, E. C., Shaffner, D. H., Garrett, E. S., Fackler, J.C. (2003). Noise, stress, and annoyance in a pediatric intensive care unit. Crit Care Med, 31(1), 113-9.

15. Karadağ, S. (2003). Kayseri Devlet Hastanesinde çalışan hemşirelerin verdiği hemşirelik bakımı ve bakımı etkileyen faktörler. Erciyes Üniversitesi Sağlık Bilimleri Enstitüsü, (Yayınlanmamış Yüksek Lisans Tezi), Kayseri.

16. Türkiye Cumhuriyeti Anayasası. (2020). https://www.icisleri.gov.tr/illeridaresi/turkiyecumhuriyeti-anayasasi (Erişim Tarihi: Ocak 2020 )

17. Türk Hemşireler Derneği (THD). (2009). Yaşamını duyuyorum. Hemşireler için etik ilke ve sorumluluklar. http://www.turkhemsirelerdernegi.org.tr/files/tr/thd/meslegietigi/hemsireler-icin-etik-ilke-ve-sorumluluklar/hemsire\%20brosur.pdf (Erişim Tarihi: Ocak 2020)

18. Esen, B. (2013). Yenidoğan yoğun bakım ebe ve hemşirelerinin etik ikilemleri ve mesleki profesyonellik düzeyleri ile ilişkisi. Marmara Üniversitesi Sağlık Bilimleri Enstitüsü, (Yayınlanmamış Yükseklisans Tezi), İstanbul. 